\title{
The Alzheimer's Disease Amyloid Precursor Protein Modulates Copper-Induced Toxicity and Oxidative Stress in Primary Neuronal Cultures
}

\author{
Anthony R. White, ${ }^{1,2}$ Gerd Multhaup, ${ }^{3}$ Fran Maher, ${ }^{1,2}$ Shayne Bellingham, ${ }^{4}$ James Camakaris, ${ }^{4}$ Hui Zheng, ${ }^{5}$ \\ Ashley I. Bush, ${ }^{1,2,6}$ Konrad Beyreuther, ${ }^{3}$ Colin L. Masters, ${ }^{1,2}$ and Roberto Cappai ${ }^{1,2}$ \\ ${ }^{1}$ Department of Pathology, The University of Melbourne, Parkville, 3052 Victoria, Australia, ${ }^{2}$ The Mental Health Research \\ Institute, Parkville, 3052 Victoria, Australia, ${ }^{3}$ Center for Molecular Biology, The University of Heidelberg, 69120 Heidelberg, \\ Germany, ${ }^{4}$ Department of Genetics, The University of Melbourne, Parkville, 3052 Victoria, Australia, ${ }^{5}$ epartment of \\ Genetics and Molecular Biology, Merck Research Laboratories, Rahway, New Jersey 07065, and ${ }^{6}$ Department of \\ Psychiatry, and Genetics and Aging Unit, Harvard Medical School, Massachusetts General Hospital, \\ Charlestown, Massachusetts 02129
}

\begin{abstract}
The amyloid precursor protein (APP) of Alzheimer's disease can reduce copper (II) to copper (I) in a cell-free system potentially leading to increased oxidative stress in neurons. We used neuronal cultures derived from APP knock-out $\left(\mathrm{APP}^{-1-}\right)$ and wild-type (WT) mice to examine the role of APP in copper neurotoxicity. WT cortical, cerebellar, and hippocampal neurons were significantly more susceptible than their respective $\mathrm{APP}^{-1-}$ neurons to toxicity induced by physiological concentrations of copper but not by zinc or iron. There was no difference in copper toxicity between APLP2 ${ }^{-1-}$ and WT neurons, demonstrating specificity for APP-associated copper toxicity. Copper uptake was the same in WT and $\mathrm{APP}^{-1-}$ neurons, suggesting APP may interact with copper to induce a localized increase in oxidative stress through copper (I) production. This was supported by significantly higher levels of copper-induced lipid peroxidation in WT neurons. Treatment of neuronal cul-
\end{abstract}

tures with a peptide corresponding to the human APP copperbinding domain (APP142-166) potentiated copper but not iron or zinc toxicity. Incubation of APP142-166 with low-density lipoprotein (LDL) and copper resulted in significantly increased lipid peroxidation compared to copper and LDL alone. Substitution of the copper coordinating histidine residues with asparagines (APP142-166 ${ }_{\mathrm{H} 147 \mathrm{~N}, \mathrm{H} 149 \mathrm{~N}, \mathrm{H} 151 \mathrm{~N})}$ ) abrogated the toxic effects. A peptide corresponding to the zinc-binding domain (APP181-208) failed to induce copper or zinc toxicity in neuronal cultures. These data support a role for the APP copperbinding domain in APP-mediated copper (I) generation and toxicity in primary neurons, a process that has important implications for Alzheimer's disease and other neurodegenerative disorders.

Key words: Alzheimer's; copper; free radicals; culture; knockout; lipid peroxidation; neurons
Alzheimer's disease (AD) is a progressive neurodegenerative disorder characterized by amyloid plaques and neuronal cell loss or dysfunction. The major constituent of plaques is a 39-42 amino acid peptide, amyloid- $\beta$ protein $(\mathrm{A} \beta)$ (Glenner and Wong, 1984; Masters et al., 1985) derived by proteolytic processing of full-length amyloid precursor protein (APP) (Kang et al., 1987). $\mathrm{A} \beta$ has an important role in neuronal dysfunction because the peptide is toxic to neurons (Koh et al., 1990; Yankner et al., 1990). APP belongs to a multigene family containing the amyloid precursor-like proteins 1 and 2 (APLP1 and APLP2) (Wasco et al., 1992; Slunt et al., 1994). APLPs share considerable homology with APP, including metal binding sites for zinc and copper (Bush et al., 1993; Hesse et al., 1994). The zinc-binding site may regulate homophilic binding (Beher et al., 1996), interact with other ligands such as heparan sulfate (Multhaup et al., 1994), or regulate

Received Nov. 25, 1998; revised May 28, 1999; accepted Aug. 11, 1999.

This work is supported in part by grants from the National Health and Medical Research Council of Australia to C.L.M. K.B. is supported by the Deutsche Forschungsgemeinschaft and the Bundesministerium fur Forschung und Technologie. J.C. is supported by a grant from the Australian Institute of Nuclear Science and Engineering. We thank Dr. Sam Sisodia and Dr. Connie von Koch for the APLP2 ${ }^{-1-}$ mice, and we thank Denise Galatis for reading of this manuscript.

Correspondence should be addressed to Dr. Roberto Cappai, Department of Pathology, The University of Melbourne, Parkville, 3052 Victoria, Australia. Copyright (C) 1999 Society for Neuroscience $0270-6474 / 99 / 199170-10 \$ 05.00 / 0$ coagulation factor inhibition (Van Nostrand, 1995) or protein folding. Copper binding to APP may be involved in electron transfer reactions as shown by the reduction of APP-bound copper (II) to copper (I) (Multhaup et al., 1996). This process was specific for copper with no reduction of iron (III), nickel (II), magnesium (II), or cobalt (II). It involved the interaction of cysteine residues at positions 144 and 158 and additional histidine residues on the same APP molecule. The APP-Cu (I) complex could reduce hydrogen peroxide to form an APP-Cu (II)-hydroxyl radical intermediate (Multhaup et al., 1998).

Although the normal function of copper reduction by APP is not known, excessive copper (I) and hydroxyl radical $(\mathrm{OH} \cdot)$ formation can damage lipids and proteins (Gunther et al., 1995; Multhaup et al., 1996) and induce oxidative stress in neurons. Increased oxidative stress and altered copper homeostasis have been identified in AD (Deibel et al., 1996; Lovell et al., 1998) and other neurodegenerative diseases. Inherited forms of familial amyotrophic lateral sclerosis (FALS) can involve mutations in the cuproenzyme, $\mathrm{Cu} / \mathrm{Zn}$ superoxide dismutase $(\mathrm{Cu} / \mathrm{ZnSOD})$, affecting copper metabolism and oxidative stress (Wiedaupazos et al., 1996; Yim et al., 1996). In Creutzfeldt-Jakob disease (CJD), the cellular prion protein $\left(\mathrm{PrP}^{\mathrm{c}}\right)$ binds copper (Brown et al., 1997a) and may be associated with lower $\mathrm{Cu} / \mathrm{ZnSOD}$ activity in PrP-deficient neurons (Brown et al., 1997b) and increased sus- 
Table 1. Amino acid sequences of APP-derived peptides

\begin{tabular}{llcc} 
Peptide & Amino acid sequence & Metal binding \\
\hline APP142-166 & DVCETHLHWHTVAKETCSEKSTNLH & $\mathrm{Cu}$ & Wild-type \\
APP142-166 & DVCETNLNWWNTVAKETCSEKSTNLH & - & H147N, H149N, H151N \\
APP181-208 & GVEFVCCPLAEESDNVDSADAEEDDSDV & Zn & Wild-type
\end{tabular}

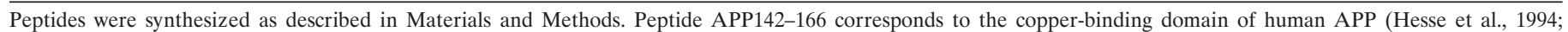

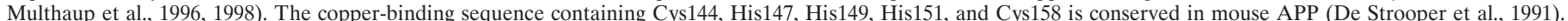

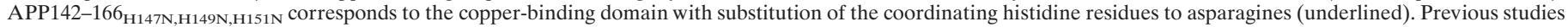
have shown these changes prevent copper binding (Hesse et al., 1994). APP181-208 corresponds to the human APP zinc-binding domain (Bush et al., 1993).

ceptibility to copper toxicity and other forms of oxidative stress (Brown et al., 1998a).

To test the hypothesis that APP can interact with copper and mediate oxidative stress in neurons (Multhaup et al., 1996, 1998), we compared the effect of copper exposure on cultures of APP knock-out $\left(\mathrm{APP}^{-1-}\right)$ and wild-type (WT) neurons. We found that WT neurons were more susceptible than $\mathrm{APP}^{-/-}$neurons to physiological concentrations of copper but not other metals. The WT neurons had increased levels of lipid peroxidation products consistent with copper-mediated oxidative stress. Similar effects were obtained with a peptide containing the APP copper-binding domain. These data demonstrate a copper-APP association that is relevant to AD.

\section{MATERIALS AND METHODS}

Materials. Poly-L-lysine, 3,[4,5 dimethylthiazol-2yl]-2,5 diphenyltetrazolium bromide (MTT), cytosine arabinofuranoside (Ara C), glycine, human low-density lipoprotein (LDL), bathocuproine disulphonate (BC), thiobarbituric acid (TBA), and butylated hydroxytoluene (BHT) were purchased from Sigma (St. Louis, MO). Metal salts were obtained from Ajax Chemicals. Glutamine, glutamate, glucose, B27 and N2 supplements, and gentamycin sulfate were obtained from Life Technologies (Gaithersburg, MD). Fetal calf serum (FCS) and horse serum (HS) were from the Commonwealth Serum Laboratories. The lipid peroxidation kit LPO 586 was obtained from Oxis International (Portland, OR).

Primary neuronal cultures. The generation of the $\mathrm{APP}^{-/-}$and APLP2 ${ }^{-1-}$ mice has been previously described (Zheng et al., 1995; von Koch et al., 1997). Control WT mice (C57BL6J $\times 129 / \mathrm{Sv}$ ) correspond to genetically matched mice from which the knock-out mice were derived. Primary neuronal cultures of cerebral cortex, cerebellum, and hippocampus were established from knock-out and WT mice as previously described (White et al., 1998). Cortical astrocyte cultures were prepared in the same manner as neuronal cultures, however, cells were plated at a density of 100,000 cells $/ \mathrm{cm}^{2}$ from embryonic day 16 (E16) mice, and the media were replaced with fresh serum-containing media after day 7 . This method was found to produce confluent astrocyte cultures with few surviving neurons at day 10. MTT assays of astrocyte cultures revealed $<10 \%$ difference in readings between wells.

Measurement of cell viability. Cell viability was determined using the MTT assay as previously described (White et al., 1998). Culture medium was replaced with $0.6 \mathrm{mg} / \mathrm{ml} \mathrm{MTT} \mathrm{in} \mathrm{control} \mathrm{salt} \mathrm{solution} \mathrm{(CSS),} \mathrm{pH} 7.4$, for $2 \mathrm{hr}$. The MTT solution was removed, and cells were solubilized with dimethylsulfoxide. Aliquots of $100 \mu \mathrm{l}$ were measured with a spectrophotometer at $570 \mathrm{~nm}$. Cell death was determined from culture supernatants using a lactate dehydrogenase (LDH) cytotoxicity detection kit (Boehringer Ingelheim).

Treatment of cultures with metals. Atomic absorption analysis of copper levels in serum-free medium before addition of $\mathrm{CuCl}_{2}$ revealed a background copper level of $\sim 0.2 \mu \mathrm{mol} / 1$. Three- or 6-d-old neuronal cultures were washed twice with serum-free media, and copper, iron, and zinc were applied in fresh serum-free media for $16 \mathrm{hr}$ or $3 \mathrm{~d}$. For copperglycine treatment (Brown et al., 1997a), a solution of $5 \mathrm{~mm} \mathrm{CuCl}_{2}$ was incubated with a tenfold molar excess of glycine before treatment of cultures. Cell viability was determined using the MTT assay.

Treatment of cultures with peptides. Peptides of APP142-166 [corresponding to the human APP copper-binding domain and demonstrating copper reducing activity (Multhaup et al., 1998)], APP142-166 ${ }_{\mathrm{H} 147 \mathrm{~N}}$, H149N, H151N (APP142-166 with histidine to asparagine substitutions at positions 147, 149, and 151) and APP181-208 (the human APP zinc-binding domain) (Table 1) were synthesized by manual 9-fluorenilmethoxycarbonyl chemistry and purified by reverse phase-HPLC. Peptides were made as $2 \mathrm{mg} / \mathrm{ml}$ stock solutions in $\mathrm{dH}_{2} \mathrm{O}$ and added to APP ${ }^{-1-}$ cortical cultures as indicated with or without metals (in MEM/N2 media) at day 2 in vitro. Cell survival was determined with the LDH assay.

Measurement of ${ }^{64} \mathrm{Cu}$ uptake and accumulation. Six-day-old primary cortical neuron cultures grown in MEM/N2 were used for ${ }^{64} \mathrm{Cu}$ uptake assays. The growth media was replaced with fresh MEM/N2 containing $5-10 \mu \mathrm{Ci} / \mathrm{ml}{ }^{64} \mathrm{Cu}$ (Australian Radioisotopes, Lucas Heights, New South Wales, Australia) and "no added copper" (trace) or medium with added "cold" $\mathrm{CuCl}_{2}$ to give a total copper concentration of $50 \mu \mathrm{M}$. After incubation at $37^{\circ} \mathrm{C}$ for $0.5,4,16$, and $24 \mathrm{hr}$, cells were lysed in $0.1 \%$ SDS, $2 \mathrm{~mm}$ EDTA and collected in sterile $10 \mathrm{ml}$ plastic tubes. ${ }^{64} \mathrm{Cu}$ was measured in cell pellets using an LKB-Wallac (Gaithersburg, MD) Ultragamma counter and expressed as picomoles of $\mathrm{Cu}$ per microgram of protein.

Determination of lipid peroxidation in cultures. Lipid peroxidation was determined in cultures using the LPO 586 lipid peroxidation kit. $\mathrm{CuCl}_{2}$ or $\mathrm{FeCl}_{2}$ was added to 6-d-old cultures as for MTT assays, however, after $16 \mathrm{hr}$ exposure to metals, the cells were extracted and processed as described in the kit instructions. A malondialdehyde (MDA) standard curve was established from 1,1,3,3 tetramethoxypropane supplied in the kit. The protein concentration of cell extracts was determined using a BCA protein assay kit (Pierce, Rockford, IL), and lipid peroxidation was calculated as nanomoles of MDA per milligram of protein and converted to percentage of untreated controls. As an additional measure of oxidative stress, the level of thiobarbituric acid-reactive substances (TBARS) was determined in metal-treated cultures. After exposure to $\mathrm{CuCl}_{2}$ or $\mathrm{FeCl}_{2}$ for $16 \mathrm{hr}, 400 \mu \mathrm{l}$ of TBA solution (15\% trichloroacetic acid, $1.25 \%$ $\mathrm{TBA}$, and $5.5 \% \mathrm{HCl}$ ) was added to each culture well containing $600 \mu \mathrm{l}$ medium (in 24 well plates). The supernatant from each well was transferred to a fresh $10 \mathrm{ml}$ tube and heated at $95^{\circ} \mathrm{C}$ for $20 \mathrm{~min}$, cooled to RT, and spun at $3000 \times g$ for $5 \mathrm{~min}$ to pellet precipitated protein. The clarified supernatant was read on a Bio-Rad (Hercules, CA) plate reader at $532 \mathrm{~nm}$. Cell-free medium alone was incubated with the TBA solution as above and subtracted from test readings. The TBARS values are given as optical density (OD) units $\left(\times 10^{-3}\right)$ /well. Cell numbers were determined by cell viability and total protein (BCA) assays. To prevent oxidation during the extraction or incubation processes, $0.01 \%$ BHT dissolved in $100 \%$ ethanol was added to buffers.

Determination of $L D L$ peroxidation by APP peptides. To measure the ability of APP peptides to induce lipid peroxidation, $0.5 \mathrm{mg} / \mathrm{ml}$ human LDL was incubated with $\mathrm{CuCl}_{2}(20 \mu \mathrm{M})$ or $\mathrm{ZnCl}_{2}(50 \mu \mathrm{M})$ and APP peptides $(140 \mu \mathrm{M})$ in PBS $(\mathrm{pH} 7.4)$ for $16 \mathrm{hr}$ at $37^{\circ} \mathrm{C}$. The level of lipid oxidation was measured using the LPO 586 lipid peroxidation kit as described above. Lipid peroxidation was determined as nanomoles of MDA per milligram of LDL and converted to percentage of control (LDL and $\mathrm{CuCl}_{2}$ ).

Statistical analysis. Data represents the mean and SEM of experiments performed in at least three or four cultures measured in triplicate. In all cases, comparison of data was performed with ANOVA and NewmanKeuls tests.

\section{RESULTS}

Wild-type primary cortical neurons are more susceptible to copper toxicity than APP ${ }^{-/-}$neurons

There were no differences in cell viability between the WT, $\mathrm{APP}^{-/-}$, or APLP2 ${ }^{-/-}$neurons in untreated cortical, cerebellar, or hippocampal cultures (data not shown). This indicates that 
under the basal culture conditions used, endogenous APP or APLP2 expression does not affect neuronal survival.

The reduction of copper (II) to copper (I) by APP has the potential to generate reactive oxygen species (ROS), which can induce oxidative stress (Multhaup et al., 1996, 1998). To determine if this can occur in a cellular environment, 6-d-old WT and $\mathrm{APP}^{-1-}$ primary cortical neuronal cultures were exposed to $\mathrm{CuCl}_{2}$ for $16 \mathrm{hr}$. As shown in Figure $1 \mathrm{~A}$, WT neurons revealed significantly lower viability ( $\sim 20 \%$ lower) than $\mathrm{APP}^{-1-}$ neurons exposed to 10 and $100 \mu \mathrm{M}$ copper $(* p<0.01$ ). Higher concentrations of copper $(500$ and $1000 \mu \mathrm{M})$ resulted in matching cell loss in both WT and APP ${ }^{-/-}$cultures. These findings were confirmed with the LDH cell survival assay. Exposure to $10 \mu \mathrm{M}$ $\mathrm{CuCl}_{2}$ for $16 \mathrm{hr}$ resulted in $83 \pm 1.2 \%$ cell survival in WT neurons compared to $98 \pm 1.6 \%$ in $\mathrm{APP}^{-1-}$ neurons $(p<0.05)$. Similar levels of toxicity were obtained with $\mathrm{CuSO}_{4}$ (data not shown) indicating that the toxic effect is not dependent on the type of copper salt. A longer exposure to $\mathrm{CuCl}_{2}$ for $3 \mathrm{~d}$ resulted in significantly increased toxicity in WT compared to $\mathrm{APP}^{-1-}$ neurons at 5 and $50 \mu \mathrm{M}$ copper $(* p<0.05$; $* *<0.01)$ but not at $100 \mu \mathrm{M}$ copper (Fig. $1 B$ ).

To determine if the increased toxicity in WT cultures was specific for copper, we tested zinc [APP contains a zinc binding domain (Bush et al., 1993)] and iron (another redox reactive transition metal). There were no differences in viability between WT and $\mathrm{APP}^{-1-}$ cortical neurons exposed to 60 and $90 \mu \mathrm{M}$ $\mathrm{ZnCl}_{2}$ or with any concentration of $\mathrm{FeCl}_{2}$ or $\mathrm{FeCl}_{3}$ tested (Fig. $1 C, D)$, whereas $100 \mu \mathrm{M} \mathrm{ZnCl} l_{2}$ induced significantly lower cell viability in WT neurons $\left({ }^{*} p<0.05\right)$ (Fig. $\left.1 C\right)$. The large increases in toxicity between 60 and $70 \mu \mathrm{M}$ and 90 and $100 \mu \mathrm{M} \mathrm{ZnCl}{ }_{2}$ may indicate the ability of zinc to induce toxicity in neuronal cultures through increased activation of ionotropic glutamate receptors (Manev et al., 1997). Specific interaction of zinc with these receptors may have induced the threshold effect observed in our cultures. Significantly, there was no difference in the level of zinc toxicity between APP ${ }^{-1-}$ and WT neurons except at the highest concentration $(100 \mu \mathrm{M})$. The low level of cell viability observed at this concentration suggests that the difference is not physiologically relevant.

Because copper is normally complexed to other molecules such as amino acids in vivo (Linder, 1991; Brown et al., 1997a), we tested the neurotoxicity of copper chelated as a copper-glycine complex. This form of copper induced significantly greater toxicity in WT as compared to $\mathrm{APP}^{-/-}$neurons at 150 and $200 \mu \mathrm{M}$ $\left({ }^{* *} p<0.05 ; * * * p<0.01\right)(\sim 50 \%$ lower viability in WT neurons exposed to $150 \mu \mathrm{M}$ copper; Fig. $1 E$ ). These data show that copper is toxic to primary neurons from WT and APP-deficient mice, however, both unbound and biologically chelated copper can induce greater toxicity in APP-expressing neurons at copper concentrations within the physiological range of 10-250 $\mu \mathrm{M}$ (Kardos et al., 1989; Linder, 1991), thus supporting the physiological relevance of these data.

If copper (I) generation by APP is responsible for increased copper toxicity in WT neurons, then chelation of copper (I) should abrogate toxicity. To test this, cultures were treated with the copper (I) chelator $\mathrm{BC}(50 \mu \mathrm{M})$ and $50 \mu \mathrm{M} \mathrm{CuCl}_{2}$. This resulted in the abolition of copper toxicity in WT neurons with no effect on $\mathrm{APP}^{-1-}$ neurons (Fig. $1 B$ ). A higher concentration of BC $(80 \mu \mathrm{M})$ completely inhibited toxicity induced by $50 \mu \mathrm{M}$ copper in both WT and APP ${ }^{-/-}$cultures (data not shown). These data support a role for copper (I) formation in mediating increased toxicity in WT compared to $\mathrm{APP}^{-1-}$ neurons.

\section{No alterations in copper toxicity in APLP2 ${ }^{-1-}$ neurons}

APP and APLP2 are the most closely related members of the APP superfamily (Hesse et al., 1994), and APLP2 has the ability to reduce copper in vitro (Multhaup et al., 1996). To test whether APLP2 affects neuronal copper toxicity, we exposed APLP2 knock-out (APLP2 ${ }^{-/-}$) and WT neurons to $\mathrm{CuCl}_{2}$ for $16 \mathrm{hr}$ or $3 \mathrm{~d}$. There was no difference in copper toxicity between WT and APLP2 $2^{-/-}$neurons using the same concentrations of copper that induced a difference between $\mathrm{WT}$ and $\mathrm{APP}^{-1-}$ neurons (Fig. $1 F)$. Therefore, basal levels of neuronal APLP2 may not mediate copper toxicity, or APLP2-associated toxicity could be masked by increased susceptibility to oxidative stress in APLP2 $2^{-/-}$neurons. These findings demonstrate that decreased copper toxicity in $\mathrm{APP}^{-1-}$ neurons is caused by a difference in APP expression and is not an artifact related to the gene knock-out procedure.

\section{Copper toxicity is increased in WT compared to $\mathrm{APP}^{-/-}$primary neuronal cultures from cerebellumand hippocampus}

If the increased copper toxicity observed in WT cortical neurons is related to the copper-binding domain on APP, similar differences in toxicity should be seen in other APP-expressing neuronal populations. To test this, we exposed WT and APP ${ }^{-/-}$cerebellar granule neurons (CGNs) and hippocampal neurons to $\mathrm{CuCl}_{2}$ at day 6 in vitro (Fig. $2 A, B$ ). WT CGNs and hippocampal neurons were significantly more susceptible to copper toxicity than their respective $\mathrm{APP}^{-1-}$ cultures (* $p<0.01$; ${ }^{* *} p<0.05$; Fig. $2 A, B$ ) within the physiological range for copper. In contrast, astrocyte cultures revealed no significant difference in cell viability between WT and $\mathrm{APP}^{-1-}$ cultures (Fig. $2 C$ ), suggesting that increased antioxidant levels in astrocytes may compensate for APPassociated copper toxicity.

\section{A peptide encoding the APP copper-binding domain potentiates copper toxicity in primary neuronal cultures}

We have previously demonstrated that the copper-binding domain of APP induces copper (I) and hydroxyl radicals in a cell-free system (Multhaup et al., 1996, 1998). To determine if this region of APP is responsible for the increased copper toxicity observed in WT neurons, we exposed APP ${ }^{-1-}$ cortical cultures to peptides containing the APP copper-binding domain (APP142166) or the APP zinc-binding domain (APP181-208) (Table 1) and subtoxic levels of $\mathrm{CuCl}_{2}$. Cultures were exposed to 5-100 $\mu \mathrm{M}$ APP142-166 with and without $5 \mu \mathrm{M} \mathrm{CuCl}{ }_{2}$ and assayed for release of $\mathrm{LDH}$ after $3 \mathrm{~d}$ (Fig. $3 A$ ). No significant increase in LDH release was observed in cultures treated with APP142-166 alone at any concentration. However, cultures exposed to $5 \mu \mathrm{M}$ $\mathrm{CuCl}_{2}$ and $10 \mu \mathrm{M}$ APP142-166 or greater produced a clear dose-response effect with a significant increase in LDH levels compared to copper alone (* $p<0.05$; * $p<0.01$; Fig. $3 A$ ). This was a specific effect because the CuBD mutant peptide, APP142$166_{\mathrm{H} 147 \mathrm{~N}, \mathrm{H} 149 \mathrm{~N}, \mathrm{H} 151 \mathrm{~N}}$ and the zinc-binding domain peptide, APP181-208 $(70 \mu \mathrm{M})$ had no affect on LDH release alone or when applied with $5 \mu \mathrm{M} \mathrm{CuCl}_{2}$ (Fig. $3 A$ ). This activity is specific for copper because $70 \mu \mathrm{M}$ APP142-166 did not potentiate either $\mathrm{FeCl}_{2}$ - or $\mathrm{ZnCl}_{2}$-induced $\mathrm{LDH}$ release (Fig. $3 A$ ). These data indicate that the human APP copper-binding domain specifically potentiates cell death from low concentrations of copper.

Free radical damage in neurons can be measured as lipid peroxidation products such as MDA. To determine that the toxicity induced by the APP copper-binding domain is related to 
A

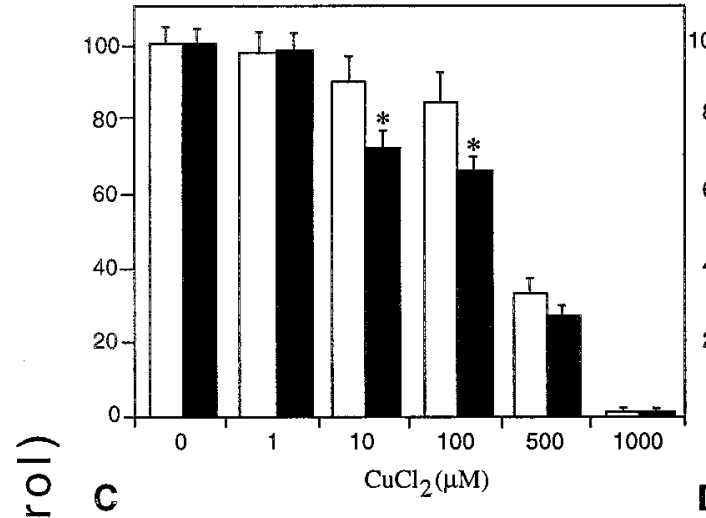

D
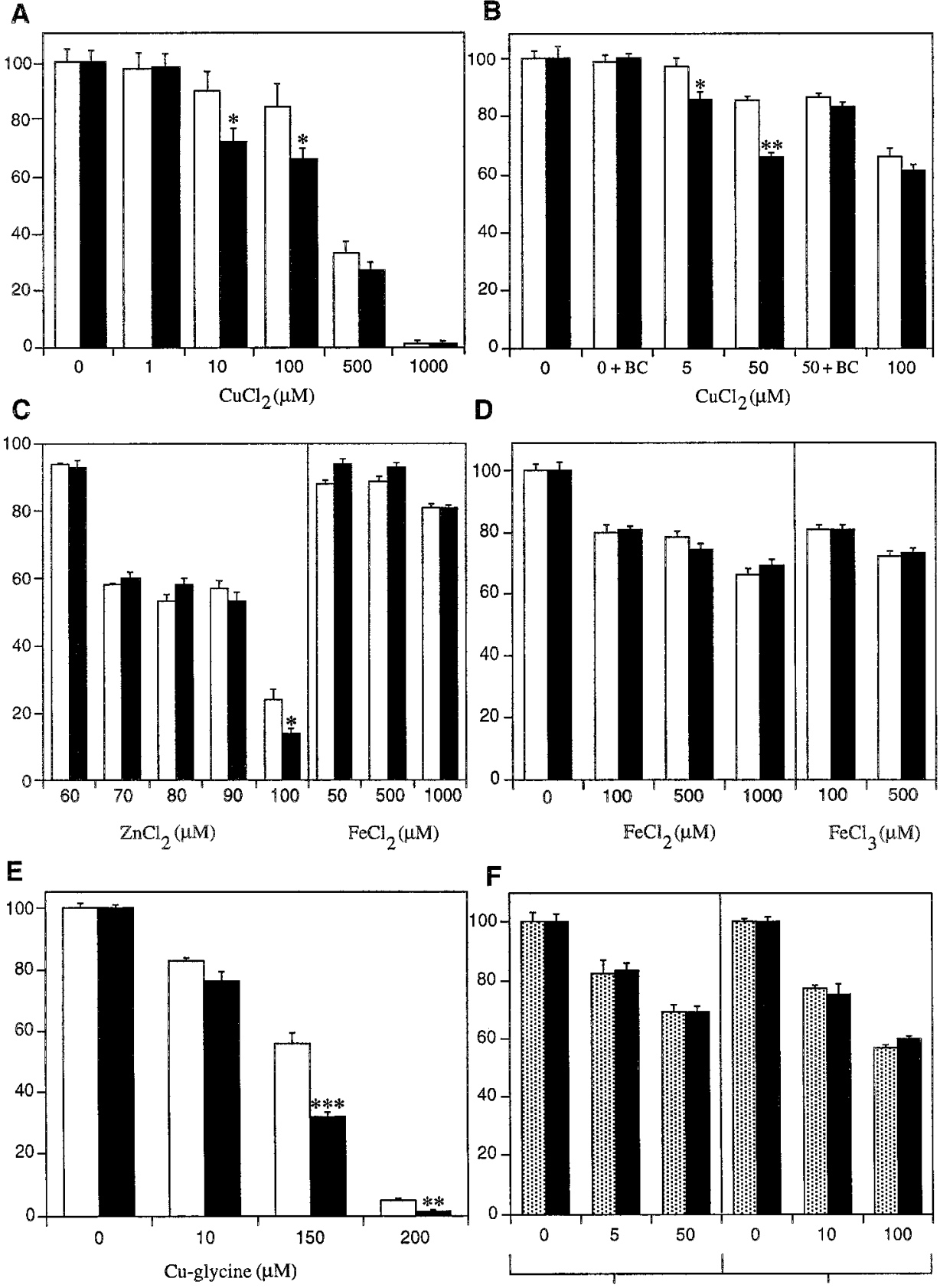

$\mathbf{F}$

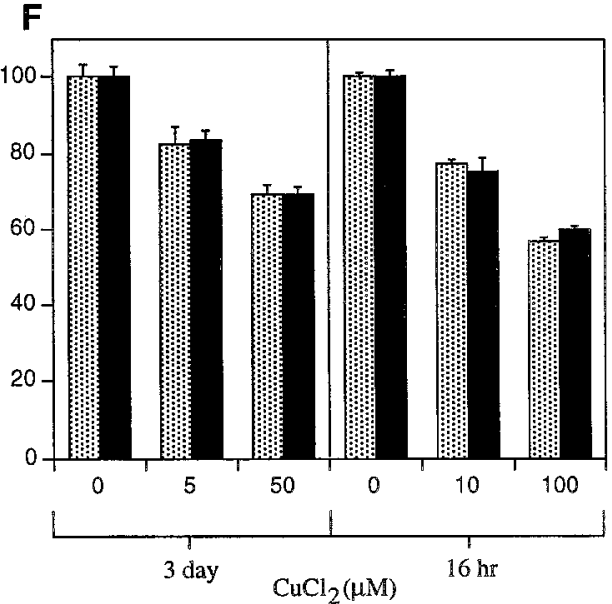

Figure 1. Effects of metals on cell viability in primary cultures of WT, $\mathrm{APP}^{-1-}$, and APLP2 ${ }^{-1-}$ cortical neurons. Three- or 6-d-old primary cortical neuronal cultures were exposed to copper, zinc, or iron salts for $3 \mathrm{~d}$ or 16 $\mathrm{hr}$, respectively, and cell viability was determined using the MTT assay. $A$, WT neurons were significantly more susceptible to 10 and $100 \mu \mathrm{M} \mathrm{CuCl}_{2}$ toxicity than $\mathrm{APP}^{-/-}$neurons after 16 hr exposure $\left({ }^{*} p<0.01\right)$. $B$, WT neurons were significantly more susceptible than $\mathrm{APP}{ }^{-/-}$neurons to 5 and 50 $\mu \mathrm{M} \mathrm{CuCl}_{2}$ toxicity after $3 \mathrm{~d}$ of exposure (from day 3 in vitro) $\left({ }^{*} p<0.05 ;{ }^{* *} p<\right.$ $0.01)$. The copper (I) chelator BC (50 $\mu \mathrm{M})$ inhibited $50 \mu \mathrm{M} \mathrm{CuCl}_{2}$ toxicity in WT cultures with no effect on copper toxicity in $\mathrm{APP}^{-1-}$ cultures. BC (50 $\mu \mathrm{M})(O+B C)$ alone had no affect on cell viability. $C$, No significant difference in cell viability was observed between $\mathrm{WT}$ and $\mathrm{APP}^{-1-}$ cortical neurons exposed to $60-90 \mu \mathrm{M} \mathrm{ZnCl}_{2}$ for $16 \mathrm{hr}$. However, WT neurons were significantly more susceptible than APP ${ }^{-1-}$ neurons to $\mathrm{ZnCl}_{2}$ at $100 \mu \mathrm{M}$ $\left({ }^{*} p<0.05\right)$. No difference in cell viability was observed between WT and APP ${ }^{-1-}$ neurons exposed to $\mathrm{FeCl}_{2}$ for $16 \mathrm{hr} . D$, No difference in cell viability was seen in WT and $\mathrm{APP}^{-/-}$neuron cultures exposed to $\mathrm{FeCl}_{2}$ or $\mathrm{FeCl}_{3}$ for $3 \mathrm{~d}$ (from day 3 in vitro). $E$, WT neurons were significantly more susceptible than $\mathrm{APP}^{-1-}$ neurons to copper toxicity induced by 150 and $200 \mu \mathrm{M}$ copper-glycine after $3 \mathrm{~d}$ of exposure $\left({ }^{* *} p<0.05 ;{ }^{* * *} p<0.01\right)$. Glycine alone at identical concentrations had no effect on neuronal viability. $F$, No difference in cell viability was seen in WT and APLP2 $2^{-1-}$ neuron cultures exposed to $\mathrm{CuCl}_{2}$ for $16 \mathrm{hr}$ or $3 \mathrm{~d}$. copper-mediated free radical generation rather than alternative affects on cell metabolism, we added APP142-166 (140 $\mu \mathrm{M}$, the same total concentration as added to cultures) and copper (20 $\mu \mathrm{M})$ to $\mathrm{LDL}$ for $16 \mathrm{hr}\left(37^{\circ} \mathrm{C}\right)$ and measured MDA accumulation. Addition of copper to LDL induced a significant increase in lipid peroxidation compared to LDL alone. Without added copper, APP142-166, APP142-166 ${ }_{\text {H147N, H149N, H151N }}$, and APP181-208 did not significantly affect lipid peroxidation levels. In the presence of $20 \mu \mathrm{M}$ copper, APP142-166 increased lipid peroxidation by $33 \%$ compared to LDL and copper alone ( ${ }^{*} p<0.01$; Fig. $\left.3 B\right)$.

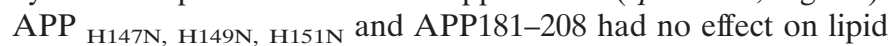
peroxidation compared to LDL and copper (Fig. 3B). Similarly, coincubation of $(50 \mu \mathrm{M}) \mathrm{ZnCl}_{2}$ with the copper or zinc-binding peptides failed to induce toxicity compared to zinc alone (Fig. $3 B$ ). These data confirm that the APP copper-binding domain can induce oxidative stress (peroxidation) through a specific interaction with copper.

\section{Wild-type and APP ${ }^{-/-}$neurons reveal similar levels of copper uptake}

The increased copper toxicity in APP-expressing cultures may be caused by greater binding and uptake of copper than in $\mathrm{APP}^{-1-}$ cultures. Alternatively, increased oxidative stress in WT cultures could result from localized generation of copper (I) by APP. ${ }^{64} \mathrm{Cu}$ 


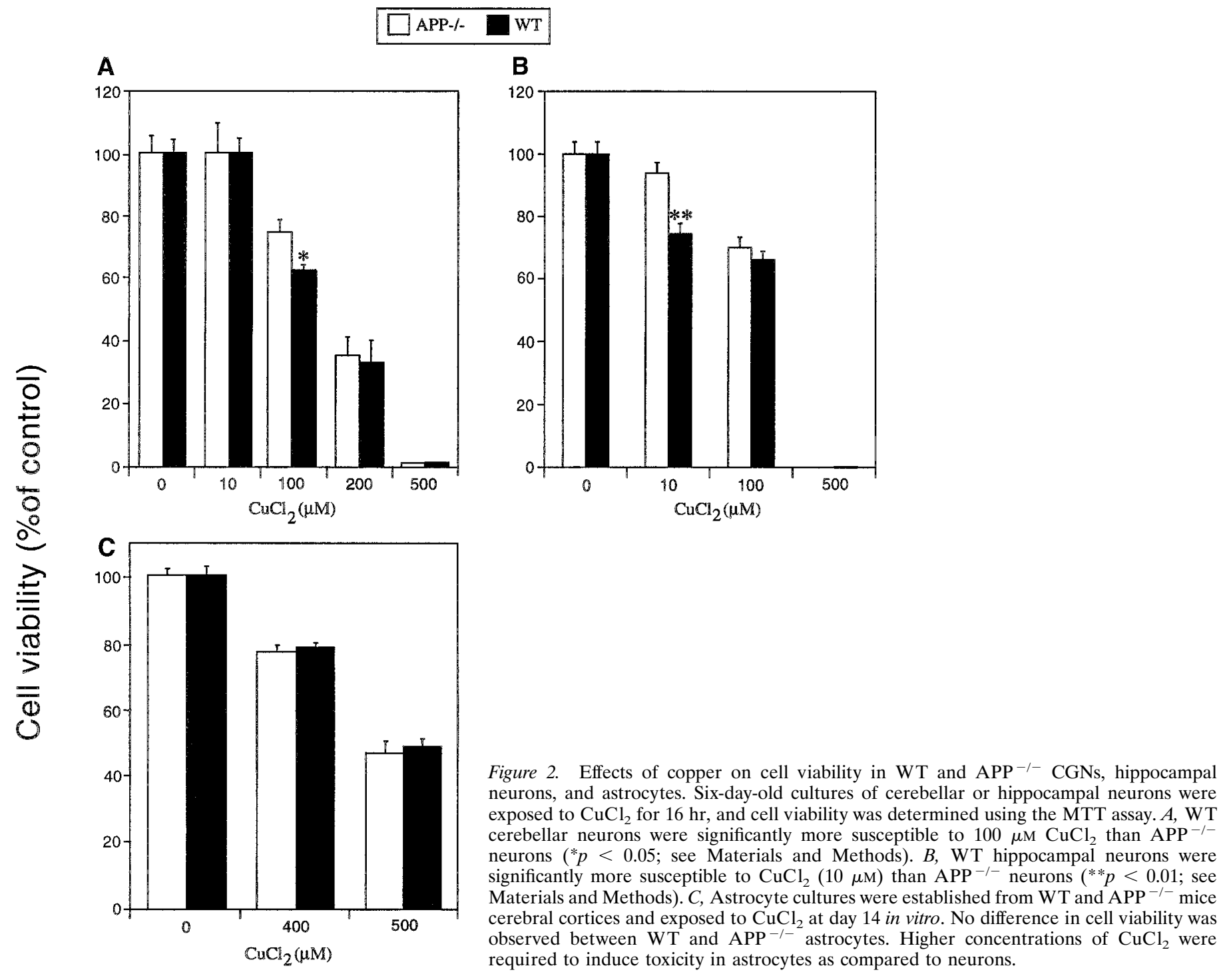

binding under the same conditions as were used to induce differential toxicity showed no significant differences in copper uptake between $\mathrm{WT}$ and $\mathrm{APP}^{-/-}$cortical neurons using either trace levels $(\sim 1 \mu \mathrm{M})$ or $50 \mu \mathrm{M} \mathrm{Cu}$ (Fig. 4). These data are consistent with APP inducing a localized increase in copper toxicity through copper (I) generation rather than increasing total copper uptake.

\section{Wild-type neurons reveal increased lipid peroxidation compared to APP ${ }^{-/-}$neurons}

To determine if increased copper toxicity in WT neurons involves the generation of oxidative stress products by APP-copper interactions, we measured MDA levels and TBA-reactive aldehyde levels. Exposure of cortical neurons to 10 and $100 \mu \mathrm{M} \mathrm{CuCl}{ }_{2}$ for $16 \mathrm{hr}$ resulted in $\sim 18$ and $13 \%$ higher levels of MDA, respectively, in WT as compared to APP ${ }^{-1-}$ cultures $(* p<0.05$; Fig. 5). Treatment of cultures with 100 and $1000 \mu \mathrm{M} \mathrm{FeCl}{ }_{2}$ resulted in no significant difference in MDA between WT and APP ${ }^{-1-}$ neurons (Fig. 5). Analysis of TBARS levels in copper-treated cultures revealed similar results. There were no differences in the basal levels of aldehydic products between $\mathrm{WT}$ and $\mathrm{APP}^{-1-}$ cultures. WT cortical neurons treated with 10 or $100 \mu \mathrm{M} \mathrm{CuCl}{ }_{2}$ for $16 \mathrm{hr}$ produced significantly greater levels ( $\sim 35$ and $20 \%$, respectively) of TBARS than APP ${ }^{-/-}$neurons $\left({ }^{*} p<0.05\right.$; Table 2$)$. In contrast, $\mathrm{FeCl}_{2}$ exposure resulted in no significant difference in TBARS levels between WT and APP ${ }^{-1-}$ cultures (Table 2). The increased copper-induced lipid peroxidation in WT neurons correlates with the greater toxicity in WT neurons measured with the MTT or LDH assays and with the increased copper toxicity induced by APP142-166.

\section{DISCUSSION}

$\mathrm{A} \beta$ deposition alone cannot explain the spatiotemporal pattern of cell loss characteristic of AD (Hardy et al., 1986). The possibility that copper may contribute to AD pathology is suggested by perturbed ceruloplasmin and copper levels in AD patients (Loeffler et al., 1996; Lovell et al., 1998) and the production of free radicals and increased $\mathrm{A} \beta$ aggregation in the presence of copper (Atwood et al., 1998, A. I. Bush, unpublished observations). There is increasing evidence that copper may also have an important role in other neurodegenerative disorders such as ALS (Andrus et al., 1998) and CJD (Viles et al., 1999; Wadsworth et al., 1999). The harmful effects of copper mis-metabolism are 
A

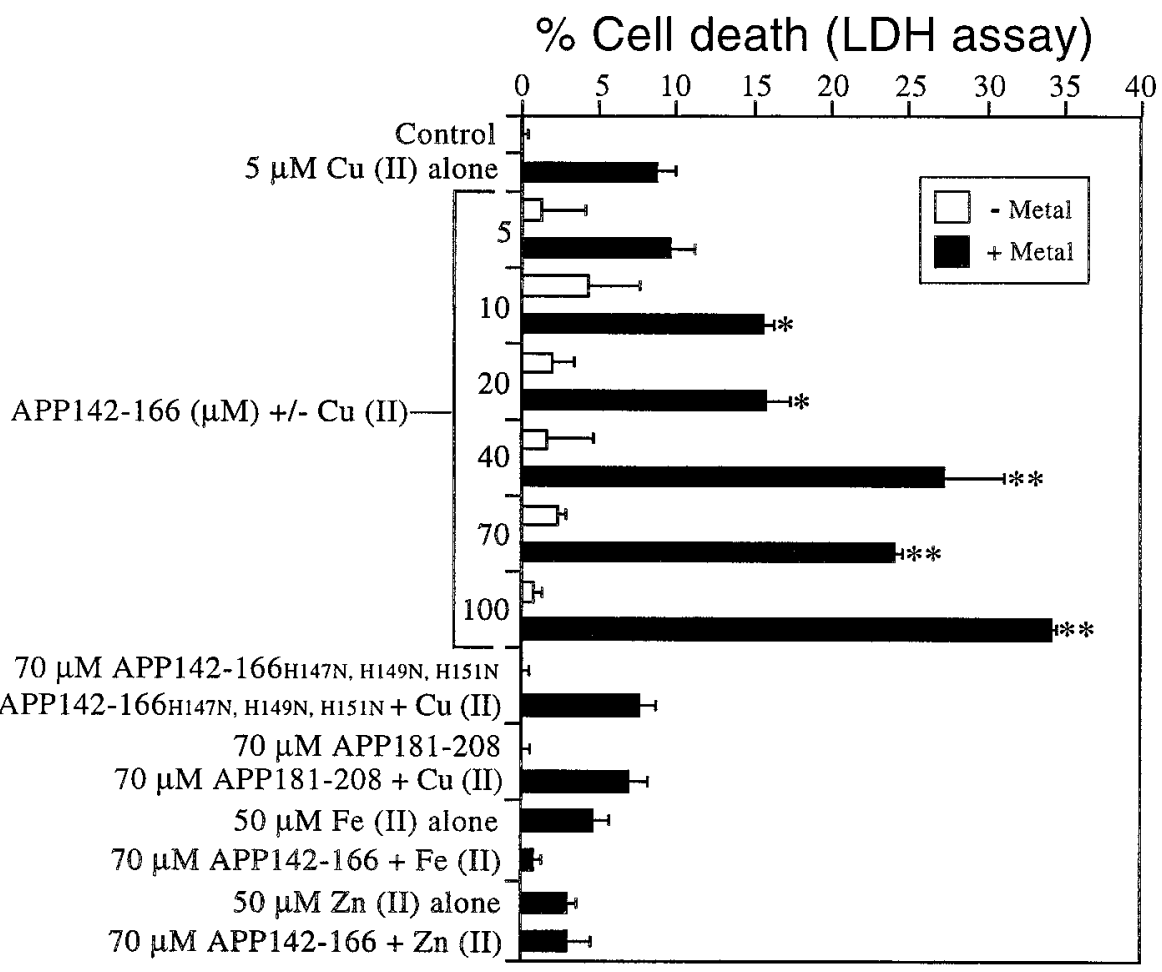

B

MDA levels (\% of LDL and Cu)

No $\mathrm{Cu}$
$\mathrm{Cu}$ (II) $(20 \mu$
$\mathrm{Zn}$ (II) $(50 \mu$
$42-166(140 \mu$
$42-166+\mathrm{Cu}$
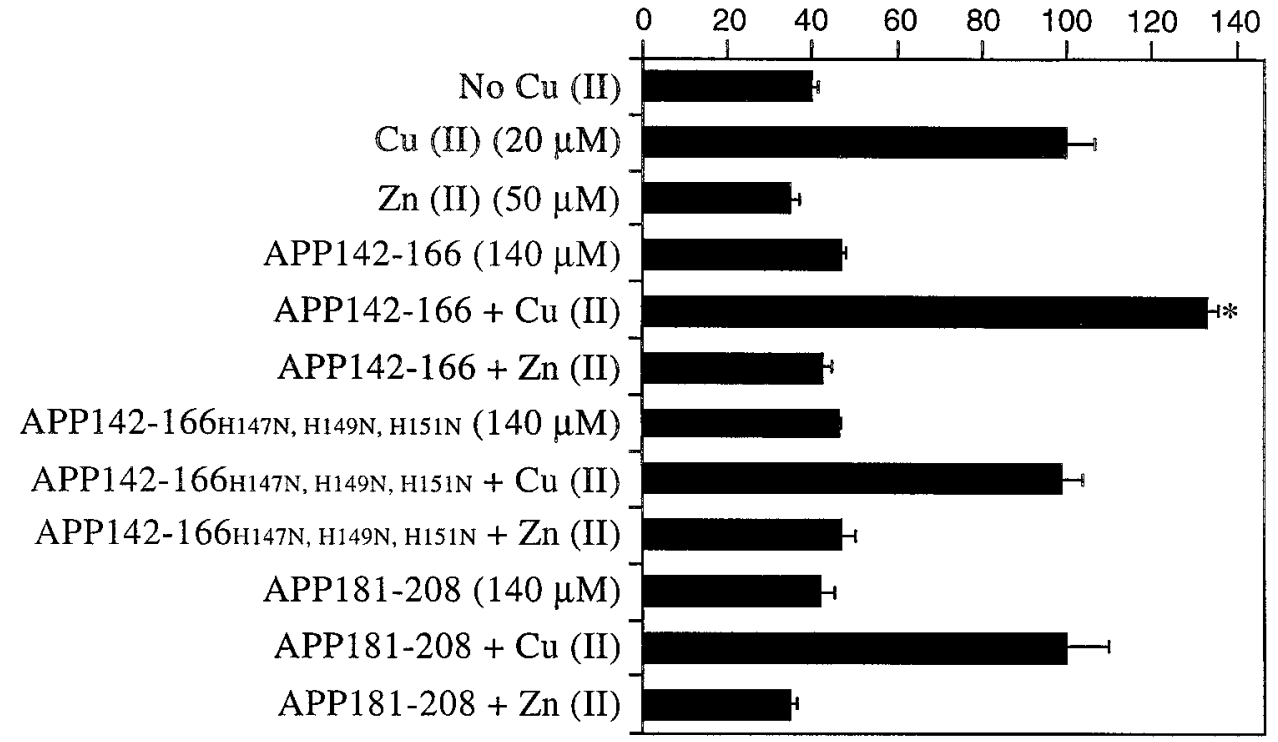

Figure 3. Potentiation of coppermediated cell death and lipid peroxidation by an APP-derived copper binding peptide. $A$, Two-day-old $\mathrm{APP}^{-1-}$ neurons were exposed to APP142-166, APP142-166 ${ }_{\text {H14N H149N, H151N }}$, or APP181208 with or without $5 \mu \mathrm{M} \mathrm{CuCl}{ }_{2}, 50 \mu \mathrm{M}$ $\mathrm{FeCl}_{2}$, or $50 \mu \mathrm{M} \mathrm{ZnCl}$ for $3 \mathrm{~d}$ in serumfree medium. APP142-166 was added at concentrations of 5-100 $\mu \mathrm{M}$ at days 1 and 2. APP142-166 ${ }_{\mathrm{H} 147 \mathrm{~N}, \mathrm{H} 149 \mathrm{~N}, \mathrm{H} 151 \mathrm{~N}}$ and APP181-208 were added at a concentration of $70 \mu \mathrm{M}$ at days 1 and $2 . \mathrm{CuCl}_{2}$, $\mathrm{FeCl}_{2}$, or $\mathrm{ZnCl}_{2}$ were added at day 1 only. Cell survival was determined with the LDH assay. APP142-166 significantly increased cell death in the presence of $5 \mu \mathrm{M} \mathrm{CuCl}_{2}$ when added at concentrations of $10 \mu \mathrm{M}$ or higher $\left({ }^{*} p<\right.$ $\left.0.05 ;{ }^{* *} p<0.01\right)$. APP142-166 $14147 \mathrm{~N}$ H149N, H151N and APP181-208 had no effect on cell death induced by $\mathrm{CuCl}_{2}$. APP142-166 had no effect on cell death induced by $\mathrm{FeCl}_{2}$ or $\mathrm{ZnCl}_{2}$. $B$, APP142166 , APP142-166 ${ }_{\mathrm{H} 147 \mathrm{~N}, \mathrm{H} 149 \mathrm{~N}, \mathrm{H} 151 \mathrm{~N}}$, and APP181-208 were incubated with 0.5 $\mathrm{mg} / \mathrm{ml} \mathrm{LDL}$ and $20 \mu \mathrm{M} \mathrm{CuCl}_{2}$ or $50 \mu \mathrm{M}$ $\mathrm{ZnCl}_{2}$ for $16 \mathrm{hr}\left(37^{\circ} \mathrm{C}\right)$. MDA levels were measured with the LPO 586 assay kit and compared to LDL incubated with $\mathrm{CuCl}_{2}$ alone. A $140 \mu \mathrm{M}$ concentration of APP142-166 (equivalent to the total concentration added to cultures) significantly increased lipid peroxidation in the presence of $20 \mu \mathrm{M} \mathrm{CuCl}_{2}\left({ }^{*} p<0.01\right)$. APP142-166 ${ }_{\mathrm{H} 147 \mathrm{~N}, \mathrm{H} 149 \mathrm{~N}, \mathrm{H} 151 \mathrm{~N}}$ and APP181208 had no effect on copper-induced lipid peroxidation. $\mathrm{ZnCl}_{2}$ did not increase lipid peroxidation induced by any peptide. highlighted by illnesses such as Menkes and Wilson's diseases (Harris and Gitlin, 1996).

We have previously reported that the APP ectodomain can bind and reduce copper (II) to copper (I) (Multhaup et al., 1996, 1998). The present data demonstrate that this reaction also occurs in a cellular environment, resulting in generation of ROS and neurotoxicity from physiological concentrations of copper (Kardos et al., 1989). This was shown by the increased susceptibility of WT as compared to APP ${ }^{-1-}$ primary neurons specifically to copper but not iron toxicity [another important mediator of oxidative stress (Xie et al., 1996)]. The increased toxicity observed in WT cortical, hippocampal, and CGN cultures with
5-150 $\mu \mathrm{M}$ copper is clearly within the proposed physiological range of $10 \mu \mathrm{M}$ for body fluid, $78 \mu \mathrm{M}$ for CSF, and $250 \mu \mathrm{M}$ for synaptic copper levels (Kardos et al., 1989; Linder, 1991). The same effect was observed when a copper-glycine complex was used in place of $\mathrm{CuCl}_{2}$, indicating that biologically bound copper can interact with APP and generate increased oxidative stress. Peptides corresponding to the APP copper-binding sequence have been shown to retain the copper reduction activity of fulllength APP (Multhaup et al., 1996, 1998). The potentiation of toxicity by the APP142-166 peptide with a subtoxic level of copper strongly supports the hypothesis that the increased copper toxicity in WT neurons is mediated by this sequence. The spec- 


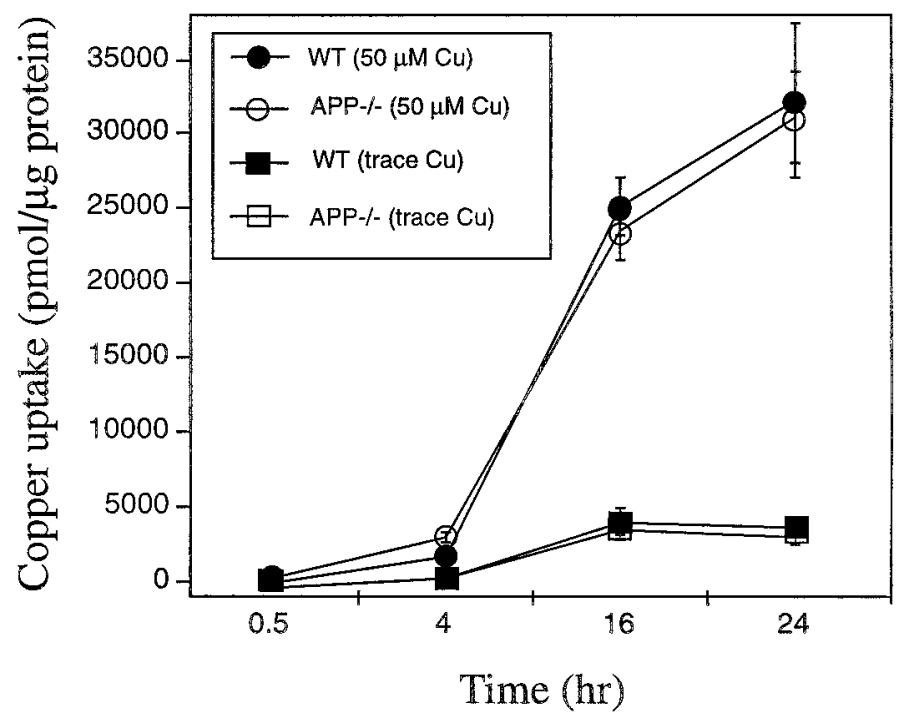

Figure 4. Copper uptake in primary cultures of $\mathrm{WT}$ and $\mathrm{APP}^{-1-}$ cortical neurons. Primary cortical cultures were exposed to ${ }^{64} \mathrm{Cu}$ in $\mathrm{MEM} / \mathrm{N} 2$ media for $0.5,4,16$, and $24 \mathrm{hr}$. Cells were lysed in $0.1 \%$ SDS and counted in an LKB-Wallac Ultragamma counter. No differences were observed in the level of copper uptake over $24 \mathrm{hr}$ between WT and $\mathrm{APP}^{-/-}$neurons.

ificity of this effect was shown by the lack of copper toxicity in cultures exposed to APP142-166 ${ }_{\mathrm{H} 147 \mathrm{~N}, \mathrm{H} 149 \mathrm{~N}, \mathrm{H} 151 \mathrm{~N}}$ or APP181208 and the inability of APP142-166 to potentiate toxicity from zinc or iron. The zinc-binding protein APP181-208 also failed to induce toxicity from $\mathrm{ZnCl}_{2}$ (data not shown). The APP-peptide concentrations used, although higher than predicted for endogenous APP levels [0.53-133 nM in CSF (Whyte et al., 1997)], are consistent with the dissociation constant $\left(K_{\mathrm{d}}\right)$ of APP142-166 for copper being $0.4 \mu \mathrm{M}$ (our unpublished observation) as compared to $10 \mathrm{~nm}$ for full-length APP (Hesse et al., 1994). This 40-fold difference in the $K_{\mathrm{d}}$ indicates the peptide would be less active, and therefore more peptide is required to compete with other soluble or cell-associated copper-binding molecules (Aschner, 1996; Loeffler et al., 1996; Brown et al., 1997a; Nishikawa et al., 1997) to induce the same level of copper reduction as full-length APP. Furthermore, the APP peptide remains soluble so a large proportion of the short-lived free radicals generated do not come into contact with the neuronal monolayer. In contrast, full-length APP is cell-associated or binds to cellular receptors and can generate a more specific and localized toxic effect. This is consistent with studies describing the need for a direct interaction between amyloidogenic peptides and neurons to induce toxicity even at peptide concentrations of $80 \mu \mathrm{M}$ (Forloni et al., 1993; Brown et al., 1996; 1998b; Ivins et al., 1998).

Interestingly, the increased neuronal toxicity induced by the APP copper-binding peptide was found to be greater when assessed with the MTT assay than with the LDH assay. As MTT provides a measure of cell viability rather than actual cell death (as determined by the LDH assay), the data suggest that the APP copper-binding sequence can reduce neuronal viability and subsequently increase susceptibility to additional oxidative insults such as $\mathrm{A} \beta$ exposure, hypoglycemia, or GSH depletion. The significant and specific potentiation of copper toxicity by APP142-166 confirms the toxic potential of the APP copperbinding sequence. Together with the observation of increased copper-induced lipid peroxidation by the APP copper-binding peptide, our data supports the hypothesis that APP can generate

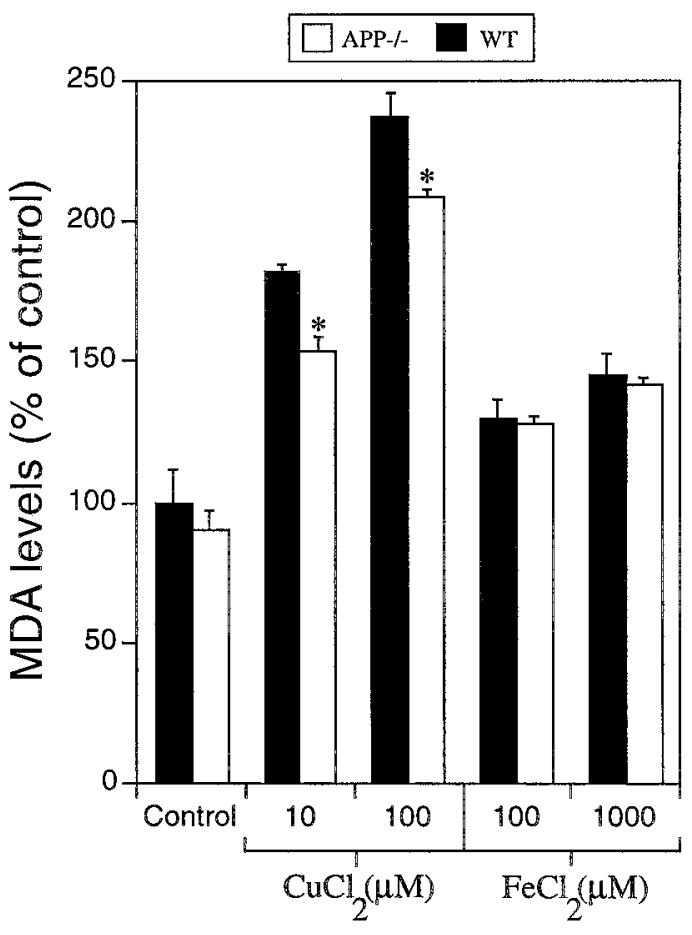

Figure 5. Malondialdehyde levels in neuronal cultures treated with copper or iron. WT and APP ${ }^{-1-}$ cortical neuronal cultures were exposed to metals at indicated concentrations for $16 \mathrm{hr}$ at day 6 in vitro. MDA levels were determined in cell extracts using the LPO 586 lipid peroxidation assay kit. Absorbance readings were compared to an MDA standard curve, adjusted for total protein concentration, and converted to percentage of control. One hundred percent MDA is equivalent to the reading for untreated WT cultures. Copper, but not iron, induced significantly greater levels of MDA (lipid peroxidation) in WT compared to $\mathrm{APP}^{-1-}$ cultures $\left({ }^{*} p<0.05\right)$.

Table 2. TBARS levels in neuronal cultures exposed to copper or iron

\begin{tabular}{lcr} 
& \multicolumn{2}{c}{ TBARS (OD Units $\times 10^{-3} /$ well) } \\
\cline { 2 - 3 } & WT & APP \\
\hline No treatment & $4 \pm 3$ & $6 \pm 4$ \\
$\mathrm{CuCl}_{2}(10 \mu \mathrm{M})$ & $41 \pm 7^{*}$ & $27 \pm 8$ \\
$\mathrm{CuCl}_{2}(100 \mu \mathrm{M})$ & $50 \pm 3^{*}$ & $41 \pm 5$ \\
$\mathrm{FeCl}_{2}(100 \mu \mathrm{M})$ & $40 \pm 8$ & $37 \pm 8$ \\
$\mathrm{FeCl}_{2}(1000 \mu \mathrm{M})$ & $75 \pm 4$ & $77 \pm 9$
\end{tabular}

$\overline{\mathrm{WT}}$ and $\mathrm{APP}^{-1-}$ cortical neuronal cultures were exposed to metals at indicated concentrations for $16 \mathrm{hr}$ at day 6 in vitro. TBA solution was added to neurons and media and incubated at $95^{\circ} \mathrm{C}$ for $20 \mathrm{~min}$. The values represent optical density (OD) units $\left(\times 10^{-3}\right)$ per well (from 24 well plates) after correction for control media alone. Copper, but not iron, induced significantly greater levels of TBARS in WT compared to $\mathrm{APP}^{-/-}$cultures.

$* p<0.05$.

copper (I) and ROS resulting in neuronal cell death. The inhibition of copper toxicity in WT cultures with the copper (I) chelator $\mathrm{BC}$ indicates that the increased toxicity in WT neurons is copper (I)-mediated. However, it is not known whether this effect is directly related to copper (I) production by APP or copper (I) oxidation of cysteine resulting in depletion of cellular glutathione.

Because WT and APP ${ }^{-1-}$ neuronal cultures showed no difference in response to other inducers of oxidative stress, including $\mathrm{A} \beta$ and $\mathrm{H}_{2} \mathrm{O}_{2}$ (Harper et al., 1998; White et al., 1998), the difference in copper toxicity in this study is not attributable to 
APP neuroprotective activity. In fact, a loss of APP expression should cause a decrease in cell survival, which is the opposite to that seen in the APP ${ }^{-/-}$neurons. The specificity of the effect with $\mathrm{APP}^{-/-}$, but not $\mathrm{APLP} 2^{-/-}$, cultures is consistent with the observation that APLP2 reduces copper (II) less efficiently than APP in a cell-free system (Multhaup et al., 1996) and is expressed at lower levels than APP. In a cellular environment, variations in primary sequence or subcellular localization may be critical for determining the level of copper reduction and therefore toxicity induced by these proteins. This could explain the higher copper toxicity in WT neurons despite a lack of difference in total copper uptake between $\mathrm{WT}$ and APP ${ }^{-1-}$ neurons. Although alternate copper transport systems (Harris et al., 1998; Nishihara et al., 1998) may compensate for the loss of APP in $\mathrm{APP}^{-1-}$ neurons, the high efficiency of copper reduction and ROS generation by APP in WT neurons would result in increased copper toxicity without an overall increase in the cellular copper level.

Interestingly, Brown et al. (1998a) have demonstrated increased copper toxicity in PrP-deficient neurons ( $\mathrm{PrP}$ is also a cuproprotein). This effect is the opposite to that shown with WT and APP ${ }^{-/-}$neurons and indicates different and specific mechanisms of copper metabolism and toxicity in each model. The increased toxicity in $\mathrm{PrP}^{-/-}$neurons may relate to their increased susceptibility to oxidative stress. Studies have shown that FALSassociated mutations to $\mathrm{Cu} / \mathrm{ZnSOD}$ may induce interactions between copper and $\mathrm{H}_{2} \mathrm{O}_{2}$, resulting in neuronal toxicity without gross changes to copper levels or SOD activity (Yim et al., 1996, 1997; Liochev et al., 1997). Similar interactions between APP, copper, and ROS may occur with little change in total cellular copper binding. This provides further evidence for the importance of metals, and in particular copper, in neurodegenerative disorders and has important implications for metal chelationbased therapy.

The increased levels of lipid peroxidation in copper-treated WT cultures and in LDL coincubated with copper and APP142166 supports our hypothesis that formation of APP-Cu (I) intermediates can result in the generation of toxic-free radicals and increased oxidative stress in neurons (Multhaup et al., 1996, 1998). This effect may be similar to the potent peroxidative activity of copper bound to human ceruloplasmin (Mukhopadhyay et al., 1997) and the demonstration of increased protein oxidation in G93A transgenic SOD1 mice (Andrus et al., 1998). Furthermore, other studies have highlighted the important role lipid peroxidation can have in neuronal oxidative stress and AD (Kruman et al., 1997; Montine et al., 1997; Sayre et al., 1997). Although increased lipid peroxidation could result from $\mathrm{A} \beta$ mediated transition metal-induced ROS production (Bondy et al., 1998), it has been found that rodent $\mathrm{A} \beta$ does not generate ROS through interactions with copper (Bush, unpublished observations). This precludes mouse $\mathrm{A} \beta$ as the source of increased copper-associated oxidative stress in our cultures. Our findings indicate that increased lipid peroxidation may be an important intermediary in APP-copper toxicity and support an earlier report of neurotoxicity from high concentrations of APP (Milward et al., 1992). These findings may be related to the accelerated degeneration of APP-transfected neurons that reveal increased APP accumulation but no change in $\mathrm{A} \beta$ levels (Nishimura et al., 1998). However, other factors may also be involved because neuronal cell loss can be achieved in APP-transfected mice lacking the copper-binding domain (Hsiao, 1998). In fact, because of the ubiquitous distribution of both copper and APP in the brain, the specific pattern of neurodegeneration in $\mathrm{AD}$ and in animal models of $\mathrm{AD}$ requires the involvement of other factors such as changes in ceruloplasmin and metalloprotein regulation, glutathione status, and $\mathrm{A} \beta$ aggregation state. $\mathrm{A} \beta$ can generate ROS from transition metals (Bondy et al., 1998) and deplete neuronal glutathione levels (an important intracellular copper detoxifying molecule) (Freedman et al., 1989; Müller et al., 1997), suggesting that A $\beta$ and APP may have multiple effects on neuronal copper toxicity. These factors could potentiate toxicity from additional stresses, including glucose deprivation, mitochondrial dysfunction, or perturbations to other neuronal antioxidant activities, all of which have been reported in AD.

Our findings demonstrating that increased oxidative damage and cell death can occur after interaction of APP and copper in a cell-based system identifies a novel role for APP in AD pathogenesis. Altered copper homeostasis has been reported in AD (Deibel et al., 1996; Loeffler et al., 1996; Lovell et al., 1998). Lovell et al. (1998) observed an increase in copper in the rim of senile plaques in AD brain, whereas Deibel et al. (1996) reported a decrease in overall copper levels in AD plaques. The apparent discrepancy in these findings could be related to the techniques used for copper measurement (micro-PIXE vs instrumental neutron activation) or tissue preparation. However, the data clearly indicate that perturbations to copper metabolism occur in AD patients, and this may result in a toxic gain of function through interaction with APP in vivo. This toxic process could contribute to the neuronal cell loss and dysfunction characteristic of AD. Furthermore, the ability of A $\beta$ to increase APP expression (Saporito-Irwin et al., 1997; White et al., 1998) could create a positive feedback loop increasing both $\mathrm{A} \beta$ production and potentially toxic APP and thus augment the role of APP in AD pathogenesis.

\section{REFERENCES}

Andrus PK, Fleck TJ, Gurney ME, Hall ED (1998) Protein oxidative damage in a transgenic mouse model of familial amyotrophic lateral sclerosis. J Neurochem 71:2041-2048.

Aschner M (1996) The functional significance of brain metallothioneins. FASEB J 10:1129-1136.

Atwood CS, Moir RD, Huang XD, Scarpa RC, Bacarra NME, Romano DM, Hartshorn MK, Tanzi RE, Bush AI (1998) Dramatic aggregation of Alzheimer A-beta by $\mathrm{Cu}$ (II) is induced by conditions representing physiological acidosis. J Biol Chem 273:12817-12826.

Beher D, Hesse L, Masters CL, Multhaup G (1996) Regulation of amyloid protein precursor (APP) binding to collagen and mapping of the binding sites on APP and collagen type I. J Biol Chem 271:1613-1620.

Bondy SC, Guo-Ross SX, Truong AT (1998) Promotion of transition metal-induced reactive oxygen species formation by $\beta$-amyloid. Brain Res 799:91-96.

Brown DR, Schmidt B, Kretzschmar HA (1996) Role of microglia and host prion protein in neurotoxicity of a prion protein fragment. Nature 380:345-347.

Brown DR, Qin K, Herms JW, Madlung A, Manson J, Strome R, Fraser PE, Kruck T, Bohlens A, Schultz-Schaeffer W, Giese A, Westaway D, Kretzschmar HA (1997a) The cellular prion protein binds copper in vivo. Nature 390:684-687.

Brown DR, Schulz-Schaeffer WJ, Schmidt B, Kretzschmar HA (1997b) Prion protein-deficient cells show altered response to oxidative stress due to decreased SOD-1 activity. Exp Neurol 146:104-112.

Brown DR, Schmidt B, Kretzschmar HA (1998a) Effects of copper on survival of prion protein knockout neurons and glia. J Neurochem 70:1686-1689.

Brown DR, Schmidt B, Kretzschmar HA (1998b) Prion protein fragment interacts with PrP-deficient cells. J Neurosci Res 52:260-267.

Bush AI, Multhaup G, Moir RD, Williamson TG, Small DH, Rumble B, Pollwein P, Beyreuther K, Masters CL (1993) A novel zinc(II) binding 
site modulates the function of the $\beta$ A4 amyloid protein precursor of Alzheimer's disease. J Biol Chem 268:16109-16112.

Deibel MA, Ehmann WD, Markesbery WR (1996) Copper, iron, and zinc imbalances in severely degenerated brain regions in Alzheimer's disease: possible relation to oxidative stress. J Neurol Sci 143:137-142.

De Strooper B, Van Leuven F, Van Den Berghe H (1991) The amyloid $\beta$ protein precursor or proteinase nexin II from mouse is closer to its human homolog than previously reported. Biochim Biophys Acta 1129:141-143.

Forloni G, Angeretti N, Chiesa R, Monzani E, Salmona M, Bugiani O, Tagliavini F (1993) Neurotoxicity of a prion protein fragment. Nature 362:543-546.

Freedman JH, Ciriolo MR, Peisach J (1989) The role of glutathione in copper metabolism and toxicity. J Biol Chem 264:5598-5605.

Glenner GG, Wong CW (1984) Alzheimer's disease and Down's syndrome: sharing of a unique cerebrovascular amyloid fibril protein. Biochem Biophys Res Commun 122:1131-1135.

Gunther MR, Hanna PM, Mason RP, Cohen MS (1995) Hydroxyl radical formation from cuprous ion and hydrogen peroxide: a spin-trapping study. Arch Biochem Biophys 316:515-522.

Hardy JA, Mann DM, Wester P, Winblad B (1986) An integrative hypothesis concerning the pathogenesis and progression of Alzheimer's disease. Neurobiol Aging 7:489-502.

Harper SJ, Bilsland JG, Shearman MS, Zheng H, Van der Ploeg L, Sirinathsinghji JS (1998) Mouse cortical neurones lacking APP show normal neurite outgrowth and survival responses in vitro. NeuroReport 9:3053-3057.

Harris ED, Qian Y, Tiffany-Castiglioni E, Lacy AR, Reddy MC (1998) Functional analysis of copper homeostasis in cell culture models: a new perspective on internal copper transport. Am J Clin Nutr 67:988S-995S.

Harris ZH, Gitlin JD (1996) Genetic and molecular basis for copper toxicity Am J Clin Nutr 63:836S-841S.

Hesse L, Beher D, Masters CL, Multhaup G (1994) The $\beta A 4$ amyloid precursor protein binding to copper. FEBS Lett 349:109-116.

Hsiao K (1998) Transgenic mice expressing Alzheimer amyloid precursor proteins. Exp Gerontol 33:883-889.

Ivins KJ, Bui ETN, Cotman CW (1998) $\beta$-amyloid induces local neurite degeneration in cultured hippocampal neurons: evidence for neuritic apoptosis. Neurobiol Dis 5:365-378.

Kang J, Lemaire H, Unterbeck A, Salbaum JM, Masters CL, Grzeschik K, Multhaup G, Beyreuther K, Müller-Hill B (1987) The precursor of Alzheimer's disease amyloid A4 protein resembles a cell-surface receptor. Nature 325:733-736.

Kardos J, Kovacs I, Hajos F, Kalman M, Simonyi M (1989) Nerve endings from rat brain release copper upon depolarization. A possible role in regulating neuronal excitability. Neurosci Lett 103:139-144.

Koh J, Yang LL, Cotman CW (1990) $\beta$-Amyloid protein increases the vulnerability of cultured cortical neurons to excitotoxic damage. Brain Res 533:315-320.

Kruman I, Bruce-Keller AJ, Bredesen D, Waeg G, Mattson MP (1997) Evidence that 4-hydroxynonenal mediates oxidative stress-induced neuronal apoptosis. J Neurosci 17:5089-5100.

Linder MC (1991) Biochemistry of copper. New York: Plenum.

Liochev SI, Chen LL, Hallewell RA, Fridovich I (1997) Superoxidedependent peroxidase activity of $\mathrm{H} 48 \mathrm{Q}$ : a superoxide dismutase variant associated with familial amyotrophic lateral sclerosis Arch Biochem Biophys 346:263-268.

Loeffler DA, LeWitt PA, Juneau PL, Sima AAF, Nguyen HU, DeMaggio AJ, Brickman CM, Brewer GJ, Dick RD, Troyer MD, Kanaley L (1996) Increased regional brain concentrations of ceruloplasmin in neurodegenerative disorders. Brain Res 738:265-274.

Lovell MA, Robertson JD, Teesdale WJ, Campbell JL, Markesbery WR (1998) Copper, iron and zinc in Alzheimer's disease senile plaques. J Neurol Sci 158:47-52.

Manev H, Kharlamov E, Uz T, Mason RP, Cagnoli CM (1997) Characterization of zinc-induced neuronal death in primary cultures of rat cerebellar granule cells. Exp Neurol 146:171-178.

Masters CL, Simms G, Weinman NA, Multhaup G, McDonald BL, Beyreuther K (1985) Amyloid plaque core protein in Alzheimer disease and Down syndrome. Proc Natl Acad Sci USA 82:4245-4249.

Milward E, Papadopoulos R, Fuller SJ, Moir RD, Small D, Beyreuther K, Masters CL (1992) The amyloid protein precursor of Alzheimer's disease is a mediator of the effects of nerve growth factor on neurite outgrowth. Neuron 9:129-137.

Montine KS, Kim PJ, Olson SJ, Markesbery WR, Montine TJ (1997) 4-hydroxy-2-nonenal pyrrole adducts in human neurodegenerative disease. J Neuropathol Exp Neurol 56:866-871.

Mukhopadhyay CK, Mazumder B, Lindley PF, Fox PL (1997) Identification of the prooxidant site of human ceruloplasmin: a model for oxidative damage by copper bound to protein surfaces. Proc Natl Acad Sci USA 94:11546-11551.

Müller WE, Romero FJ, Perovic S, Pergande G, Pialoglou P (1997) Protection of flupirtine on $\beta$-amyloid-induced apoptosis in neuronal cells in vitro: prevention of amyloid-induced glutathione depletion. J Neurochem 68:2371-2377.

Multhaup G, Bush AI, Pollwein P, Masters CL (1994) Interaction between zinc (II) and the heparin binding site of the Alzheimer's disease bA4 amyloid precursor protein (APP). FEBS Lett 355:151-154.

Multhaup G, Schlicksupp A, Hesse L, Beher D, Ruppert T, Masters CL, Beyreuther K (1996) The amyloid precursor protein of Alzheimer's disease in the reduction of copper (II) to copper (I). Science 271:1406-1409.

Multhaup G, Ruppert T, Schlicksupp A, Hesse L, Bill E, Pipkorn R, Masters CL, Beyreuther K (1998) Copper-binding amyloid precursor protein undergoes a site-specific fragmentation in the reduction of hydrogen peroxide. Biochemistry 37:7224-7230.

Nishihara E, Furuyama T, Yamashita S, Mori N (1998) Expression of copper trafficking genes in the mouse brain. NeuroReport 9:3259-3263.

Nishikawa T, Lee IS, Shiraishi N, Ishikawa T, Ohta Y, Nishikimi M (1997) Identification of $S 100 \beta$ protein as a copper-binding protein and its suppression of copper-induced cell damage. J Biol Chem 272:23037-23041.

Nishimura I, Uetsuki T, Dani SU, Ohsawa Y, Saito I, Okamura H, Uchiyama Y, Yoshikawa K (1998) Degeneration in vivo of rat hippocampal neurons by wild-type Alzheimer amyloid precursor protein overexpressed by adenovirus-mediated gene transfer. J Neurosci 18:2387-2398.

Saporito-Irwin SM, Thinskaran G, Ruffini L, Sisodia SS, Van Nostrand WE (1997) Amyloid $\beta$-protein stimulates parallel increases in cellular levels of its precursor and amyloid precursor-like protein 2 (APLP2) in human smooth muscle cultures. Amyloid Int J Exp Clin Invest 4:54-60.

Sayre LM, Zelasko DA, Harris PLR, Perry G, Salomon RG, Smith MA (1997) 4-Hydroxynonenal-derived advanced lipid peroxidation end products are increased in Alzheimer's disease. J Neurochem 68:2092-2097.

Slunt HH, Thinakaran G, von Koch C, Lo ACY, Tanzi RE, Sisodia SS (1994) Expression of a ubiquitous, cross-reactive homologue of the mouse $\beta$-amyloid precursor protein (APP). J Biol Chem 269:2637-2644.

Van Nostrand WE (1995) Zinc (II) selectively enhances the inhibition of coagulation factor XIa by protease nexin-2/amyloid $\beta$-protein precursor. Thromb Res 78:43-55.

Viles JH, Cohen FE, Prusiner SB, Goodin DB, Wright PE, Dyson HJ (1999) Copper binding to the prion protein: structural implications of four identical cooperative binding sites. Proc Natl Acad Sci USA 96:2042-2047.

von Koch CS, Zheng H, Chen H, Trumbauer M, Thinakaran G, van der Ploeg LHT, Price DL, Sisodia SS (1997) Generation of APLP2 KO mice and early postnatal lethality in APLP2/APP double KO mice. Neurobiol Aging 18:661-669.

Wadsworth JDF, Hill AF, Joiner S, Jackson GS, Clarke AR, Collinge J (1999) Strain-specific prion-protein conformation determined by metal ions. Nat Cell Biol 1:55-59.

Wasco W, Bupp K, Magendantz M, Gusella JF, Tanzi RE, Solomon F (1992) Identification of a mouse brain cDNA that encodes a protein related to the Alzheimer disease-associated amyloid $\beta$ protein precursor. Proc Natl Acad Sci USA 89:10758-10762.

White AR, Zheng H, Galatis D, Maher F, Hesse L, Multhaup G, Beyreuther K, Masters CL, Cappai R (1998) Survival of cultured neurons from APP knockout mice against Alzheimer's amyloid A $\beta$ toxicity and oxidative stress. J Neurosci 18:6207-6217.

Whyte S, Wilson N, Currie J, Maruff P, Malone V, Shafiq-Antonacci R, Tyler P, Derry KL, Underwood J, Li Q-X, Beyruther K and Masters CL (1997) Collection and normal levels of the amyloid precursor protein in plasma. Ann Neurol 41:121-124. 
Wiedaupazos M, Goto JJ, Rabizadeh S, Gralla EB, Roe JA, Lee MK, Valentine JS, Bredesen DE (1996) Altered reactivity of superoxide dismutase in familial amyotrophic lateral sclerosis. Science 271:515-518.

Xie CX, Mattson MP, Lovell MA, Yokel RA (1996) Intraneuronal aluminum potentiates iron-induced oxidative stress in cultured rat hippocampal neurons. Brain Res 743:271-277.

Yankner BA, Duffy LK, Kirschner DA (1990) Neurotrophic and neurotoxic effects of amyloid $\beta$ protein: reversal by tachykinin neuropeptides. Science 250:279-282.

Yim HS, Kang JH, Chock PB, Stadtman ER, Yim MB (1997) A familial amyotrophic lateral sclerosis-associated $\mathrm{A} 4 \mathrm{~V} \mathrm{Cu}, \mathrm{Zn}$ superoxide dis- mutase mutant has lower $\mathrm{Km}$ for hydrogen peroxide. J Biol Chem 272:8861-8863.

Yim MB, Kang JH, Yim HS, Kwak HS, Chock PB, Stadtman ER (1996) A gain of function of an amyotrophic lateral sclerosis-associated $\mathrm{Cu}, \mathrm{Zn}$ superoxide dismutase mutant: an enhancement of free radical formation due to a decrease in $\mathrm{Km}$ for hydrogen peroxide. Proc Natl Acad Sci USA 93:5709-5714.

Zheng H, Jiang MH, Trumbauer ME, Sirinathsinghji DJS, Hopkins R, Smith DW, Heavens RP, Dawson GR, Boyce S, Conner MW, Stevens KA, Slunt HH, Sisodia SS, Chen HY, Van der Ploeg LHT (1995) $\beta$-amyloid precursor protein-deficient mice show reactive gliosis and decreased locomotor activity. Cell 81:525-531. 